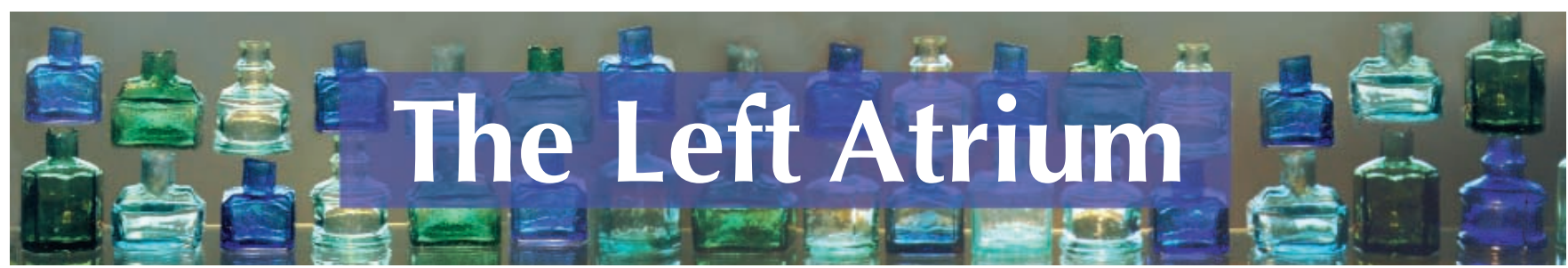

\section{A surgical history}

The knife man

Wendy Moore

London (UK): Transworld Publishers; 2005

482 pp \$40.50 (cloth) ISBN 0593-052099

$\mathrm{O}$ Dec. 12, 1785, in St. George's Hospital, London, an unnamed hackney cab driver with a popliteal artery aneurysm underwent "Hunter's operation," the successful ligation of the superficial femoral artery as it exits from Hunter's canal. The aneurysm slowly decreased in size, and six weeks later the coachman left the hospital and returned to work driving his cab. Until this success, the therapeutic choices for popliteal aneurysm had been to do nothing and await rupture, or to amputate - with death highly probable and, for those who survived the surgery, future work impossible.

Knowing from past attempts that ligation near the aneurysm would fail, John Hunter - the knife man tested his theory of collateral circulation on dogs and the growing horns of a stag. On the basis of these experiments and his knowledge of anatomy, Hunter ligated the aneurysmal artery where it was normal. Contrary to the expectations of Hunter's unremittingly hostile colleagues, the limb survived. A year later, the coachman died of unrelated causes. Hunter somehow acquired the leg and dissected out the artery, demonstrating the collateral circulation that had formed after ligation. He closed the loop of the scientific method: hypothesis, experiment, clinical application and evaluation of results. This was translational research in another era.

Thus we are introduced by Wendy Moore to the father of scientific surgery, John Hunter. Interestingly, despite his catholic interests and his scientific work in human and comparative anatomy, surgery, medicine, physiology, origin of the species and geology, Hunter was slow to publish. It was an Italian observer who recorded his operation for popliteal aneurysm, which in London, France and Italy became the standard management of this common problem.

Born in 1728 at the family home of Long Calderwood, John Hunter was not a student content at school but a student of life in all its forms. Although he abandoned formal education at age 13 , his boundless curiosity seems to have been satisfied on the family farm and on the hills of Lanarkshire. Given that he was unable to read or write until his teens, it is likely he had dyslexia. Although, in later years, publications through the Royal Society and an extensive correspondence show Hunter to be perfectly literate, he preferred to dictate and for others to write for him. At 20, he joined his brother William at his anatomy school in Covent Garden as an assistant; here, he dissected, taught and studied, becoming within 12 years the foremost anatomist in England. Short periods over summers spent with William Cheselden in Chelsea and Percivall Pott at St. Bartholomew's, and five months as house surgeon at St. George's provided his formal surgical training. During his time with William, Hunter made countless anatomic preparations and discoveries that his brother claimed as his own. It was priority and credit over the dis- covery of placental circulation that led ultimately to the rupture of their relationship. In 1760, during the Seven Years War, John joined the army as surgeon and was sent to Belle-Ile, off Brittany, and then to Portugal. This experience led to major controversy over the management of gunshot wounds. Hunter had observed that enlarging wounds to remove the missile led to infection and often death. Observing four French wounded who, in hiding from the English, had received no therapy yet whose wounds had healed without consequence, he adopted a nonoperative approach, flying in the face of the establishment (an unintentional trial). His reluctance to publish was evident; his Treatise on the Blood, Inflammation and Gun-shot Wounds was finished in 1793, the year he died.

Hunter was tireless. His endless intellectual curiosity sustained him in his dissecting rooms early in the morning and late at night, through rounds at St. George's and appointments with private patients, and in managing his menagerie and museum in London and the farm at Earl's Court.

One cannot imagine how he got everything done. Moore takes us through his life in 18th-century London with clarity, outstanding research and an eye to the zest for life that Hunter had. Happily married to Anne Home after a seven-year engagement, Hunter moved his household several times, along with his collection of dissections, specimens and live and stuffed animals. They settled finally in 1783 in 28 Leicester Square, a very fashionable address. Distinctly unfashionable but directly behind was 13 Castle Street, a situation that allowed the dissection rooms, the collection, 
the specimens and the museum to be joined to the family home. This schizophrenic building was well suited to the family and its many enterprises. Anne's salon, Georgian society and private patients entered the front door on Leicester Square, while resurrection men with bodies for dissection, animals of all shapes and sizes and other unmentionables arrived at the back door on Castle Street. Moore opens our eyes to the intellectual ferment and excitement of the Enlightenment as the artists Reynolds, Stubbs, Gainsborough and Copley, the writers Boswell, Johnson and Pepys, and the great scientists of the era pass through Hunter's door on

\section{Baptism}

I enter the rooms where the anxious patients wait

to learn what changelings have been left in their lives,

in their guts. I bring names for these new entities: it is time

to bring them into the light, and christen them.

These are the cataclysmic incidents of understated calm, the sort that provide key moments in medical television dramas, only I have no script, my patients are not acting,

and the lighting is poorer.

Cloaked in the white of priesthood, I carry a solemnity

not my own, granted me by Apollo.

At the awkward altar of the hospital bed,

I bow my head before the sacrifice.

I, the medical profession incarnate, declare

what I have read in the entrails, pronounce my interpretation,

foretell the remaining lifespan.

They invariably accept the speaking.

Well, thanks for being honest, Doctor,

at least now I know what the score is.

It amazes me that they accept my naming, or my compassion.

They never ask, how can you know what it is, what it means.

(Me, who's twenty-four, never had anything worse than tonsillitis, never broken anything except an adolescent heart.)

I am tempted to forget the role I play, step outside it, stand with Dylan Thomas, railing at their acceptance.

I want to yell, whether or not you know what to call it,

it's going to kill you. Even if you know what it is.

I've seen it happen many times, but still cannot fathom

why the sole act of giving a name brings relief, as if the christening made it any less deadly guess that's why baptism is a sacrament.

\section{Gwynedd Pickett}

Department of Neurosurgery

Hope Hospital

Salford, Lancs., UK

Leicester Square. The dark, seamier side of 18th-century London entered at night on the Castle Street side.

Hunter was elected to the Royal Society in 1767 , a year before his contentious appointment as surgeon at St. George's, but the weekly meetings of the Society could not satisfy his lust for scientific debate. He led a splinter group of scientists to Young Slaughter's coffee house to dine on oysters and continue discussions.

Hunter's best-known student was Edward Jenner, who "walked the wards alongside the hospital's most controversial surgeon, imbibed his iconoclastic views on treating patients, assisted as his 'dresser' in the operating theatre, and helped him in the dissecting room." They had a close relationship. As Moore explains, "It was Hunter's doctrine - of observation, experiment and application - Jenner would faithfully follow when ... he tested the smallpox vaccine." Hunter was ahead of his time in surgical technique and decision-making, the concept of evidence-based practice, lifelong learning, medical education, translational research and meritocratic administration.

If I have one cavil with this book, it is that the title comes across like a marketing device. Hunter was an 18th-century magician with the knife - in theatre and the dissection room - but also in so much more. Moore has given us a wonderfully crafted, well-researched biography of a great man. John Hunter's legacy is today twofold: a scientific, physiological approach to our surgical patients; and his museum, now housed in its beautifully refurbished setting in the Royal College of Surgeons in Lincolns Inn Fields, a short walk from the Covent Garden home of the Hunter anatomy school and from Leicester Square, where today there is a statue of this formidable man.

Jonathan L. Meakins

Nuffield Professor of Surgery

Oxford Radcliffe College

The John Radcliffe

Headington, Oxford, UK 